\title{
Flow in culverts as a potential mechanism of stream fragmentation for native and nonindigenous crayfish species
}

\author{
Hannah R. Foster ${ }^{1}$ AND Troy A. Keller ${ }^{2}$ \\ University of Michigan Biological Station, 9133 Biological Road, Pellston, Michigan 49769-9133 USA
}

\begin{abstract}
Habitat fragmentation and nonindigenous species are 2 of the leading causes of species loss globally. Thus, scientific information is needed to assess their interactive effects on the biota of lotic ecosystems. We tested the hypothesis that culverts (i.e., pipes) at road-stream intersections elevate flow velocities and differentially slow upstream locomotion of native relative to nonindigenous crayfishes. We: 1) mapped culvert locations and measured their flow; 2) quantified movement of Orconectes propinquus (native) in culverts with velocities of 2,31 , and $42 \mathrm{~cm} / \mathrm{s} ; 3$ ) compared the movement of Orconectes rusticus (nonindigenous), O. propinquus, and Orconectes virilis (native) in a culvert with velocity of $30 \mathrm{~cm} / \mathrm{s}$; and 4) used a recirculating flume to determine the water velocity that impeded upstream movement (impedance velocity) of each species. Culverts had higher velocities than upstream riffles during baseflow conditions. Orconectes propinquus moved upstream in culverts with flows $>30 \mathrm{~cm} / \mathrm{s}$, but individuals slipped more frequently and traveled slower than those tested at $2 \mathrm{~cm} / \mathrm{s}$. Orconectes rusticus moved upstream faster in culverts and had an impedance velocity $\sim 6 \mathrm{~cm} / \mathrm{s}$ faster than $O$. propinquus $(34.0 \pm 1.2 \mathrm{~cm} / \mathrm{s}$, mean $\pm 1 \mathrm{SE})$ and $\sim 8 \mathrm{~cm} / \mathrm{s}$ faster than $O$. virilis $(32.0 \pm 1.1 \mathrm{~cm} / \mathrm{s})$. Culverts impeded crayfish upstream movement differently among species. Nonindigenous species tolerated higher flows, so culverts may create a filter that favors the spread of invasive species. Culverts should be designed to keep water velocity $<30 \mathrm{~cm} / \mathrm{s}$ to mitigate flow effects on crayfish passage, thereby minimizing the possible combined effects of fragmentation and nonindigenous species introductions.
\end{abstract}

Key words: species displacement, interspecific competition, conservation, barriers, hydrodynamics, stream restoration, species invasion, flow tolerance, Orconectes rusticus, Orconectes virilis, Orconectes propinquus.

Habitat fragmentation threatens an increasing number of organisms as human populations grow and urbanization expands (Fahrig 2003) and is now considered one of the leading causes of species loss globally (Fischer and Lindenmayer 2007). The effects of fragmentation are particularly acute when resource use and gene flow become limited (Fahrig 2003, Ormerod 2003). These constraints place small, isolated populations at an elevated risk of extirpation (Vaughan 2002, Jones and Bergey 2007).

River systems also can be fragmented, resulting in indirect effects on upstream ecosystems and, potentially, the loss of species using those habitats (Pringle 1997,

\footnotetext{
${ }^{1}$ Present address: Department of Molecular and Cellular Biology, Harvard University, 52 Oxford Street, Cambridge, Massachusetts 02138 USA. E-mail: hafoa2@gmail.com

2 Present address: Department of Earth and Space Sciences, Columbus State University, 4225 University Avenue, Columbus, Georgia 31907 USA. E-mail: keller_try@columbusstate.edu
}

2001). Linear features of human transportation infrastructure, such as roads, often cross streams and rivers. At many road-stream intersections, engineers install pipes (hereafter, culverts) as an inexpensive alternative to building bridges. These structures can hamper upstream movement of fish species and separate fishes from upstream spawning/rearing habitats or feeding grounds (Utzinger et al. 1998, Ormerod 2003, Haro et al. 2004, Gibson et al. 2005, Benton et al. 2008, Park et al. 2008). One mechanism by which culverts fragment streams is to increase flow velocities (Gibson et al. 2005, Benton et al. 2008). Such elevated flows could affect behavior and movement of large benthic macroinvertebrates, such as crayfish (Maude and Williams 1983).

Crayfish serve an important ecological role in freshwater ecosystems (Corey 1988, Creed 1994, Taylor et al. 1996, Lodge et al. 2000). Most crayfish species are omnivorous (Momot 1995) and consume macroalgae, macrophytes, animals, and allochthonous materials (Momot et al. 1978, Momot 1995, Taylor 
et al. 1996). They supply resources to higher trophic levels by serving as prey for fish, mammals, and birds (Corey 1988, Rabeni 1992). The burrowing activities of crayfish transform benthic habitats and alter fluvial geomorphic processes (Statzner et al. 2000). Understanding anthropogenic effects on crayfish populations is imperative because of their importance in aquatic ecosystems. Loss of native species or a change in species composition as a result of habitat fragmentation could have ecosystem-wide ramifications.

In the US, crayfishes are the $2^{\text {nd }}$-most imperiled aquatic group as a percentage of total species (Wilcove and Master 2005). Their declines worldwide are associated with habitat fragmentation and the introduction of invasive crayfishes (Taylor et al. 1996, 2007). Culverts at road crossings may create unfavorable stream habitat conditions and sever the connection between downstream and upstream populations. In cases where invasive species also occur, native species face a combined threat that could hasten their local extinction.

Two native, surface-dwelling crayfish, Orconectes virilis and Orconectes propinquus, are widespread in aquatic habitats in northern Michigan (Creaser 1931). Both species may be negatively affected by the establishment of the nonindigenous rusty crayfish (Orconectes rusticus). This aggressive species has displaced native crayfish populations in many streams and lakes (Capelli 1982, Capelli and Munjal 1982, Butler 1985). Since the 1960s, O. rusticus has spread rapidly from the Ohio River Basin and the surrounding area throughout the northeastern US and Ontario, the midwestern US, and parts of the southern US and New Mexico and has altered the biotic assemblages of ecosystems it has colonized (reviewed in Lodge et al. 2000). The success of O. rusticus has several explanations. It grows rapidly to a large size (Hill et al. 1993), is aggressive (Hazlett et al. 1992), has high predator avoidance ability (Garvey et al. 1994), long-term memory (Hazlett et al. 2002), and fecundity (Momot 1984, Corey 1988). In addition, O. rusticus tolerated higher flow velocities than $O$. propinquus and $O$. virilis in a laboratory flume (Maude and Williams 1983). If $O$. rusticus can pass through culverts not accessible to $O$. propinquus and $O$. virilis, then culverts could function as a biological filter (Warren and Pardew 1998) that selectively facilitates the dispersal of an invasive species over its native congeners.

Information is needed to assess how human activities fragment natural systems and affect movement of native and invasive species, so that the contributions of those activities to the loss of native species can be minimized. We report results of field and laboratory experiments designed to measure how flow conditions in culverts affect the upstream

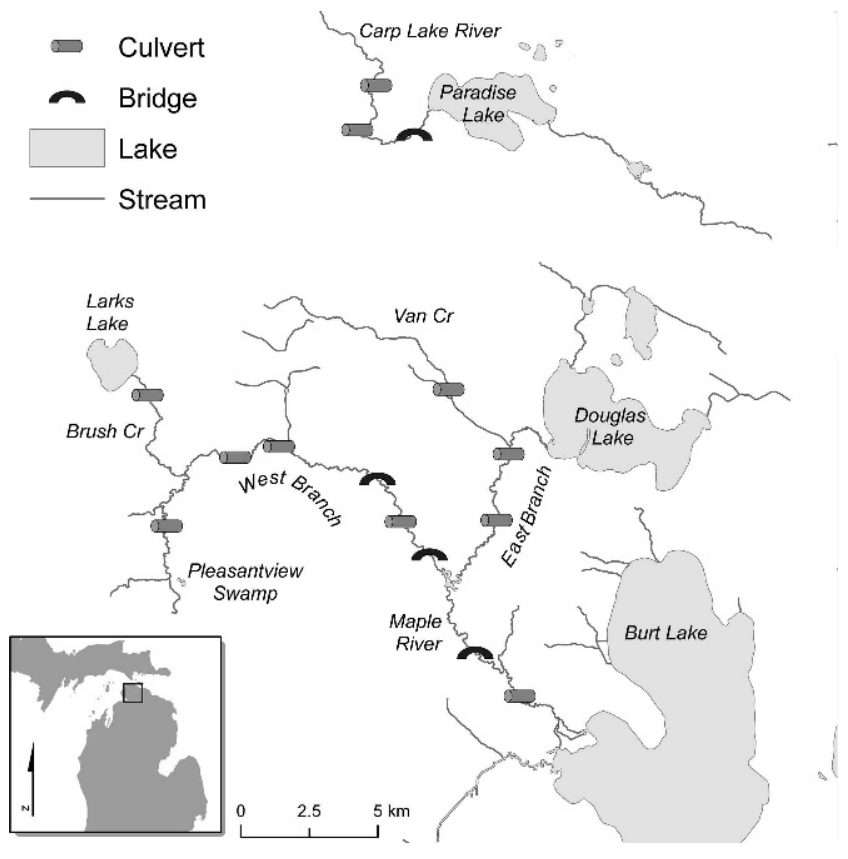

FIG. 1. Stream-road intersections with culverts (gray cylinders) sampled in northern Michigan. Most sites contained 2 or 3 culverts. $\mathrm{Cr}=$ creek.

movement of 2 native and 1 nonindigenous crayfish species. We hypothesized that: 1) culverts elevate flow velocities compared to upstream riffle segments, 2 ) crayfish have more difficulty moving upstream in culverts with elevated flows, 3 ) the nonindigenous $O$. rusticus is more successful in moving upstream through culverts than the native $O$. propinquus or $O$. virilis, and 4) higher flow velocities are needed to impede the upstream movement of $O$. rusticus than its congeners.

\section{Methods}

\section{Study area}

We studied culverts in $1^{\text {st }}$ - to $4^{\text {th }}$-order (Strahler 1957) segments of rivers in the Carp Lake and Maple River watersheds in northern, lower Michigan (mostly in Emmet County; Fig. 1). Wetlands serve as the source water for both watersheds, and their rivers ultimately discharge to Lake Michigan. The rivers drain glacial outwash materials deposited after the Pleistocene glaciation. Human densities are generally low in Emmet County $\left(174 / \mathrm{km}^{2}\right.$; US Census 2000; http://factfinder. census.gov/home/saff/main.html?_lang=en). Land cover in the Maple River watershed is dominated by forests $(65 \%)$ with some open land $(20 \%)$ but little agriculture or development $(10 \%$ and $<2 \%$, respectively; TAK, unpublished data). Road crossings with culverts are common in northern lower Michigan 
(Fig. 1). Culverts are concentrated on county roads, rather than on larger highways, which traverse streams by bridges.

\section{Culvert characteristics and locations}

We quantified the spatial distribution and flow conditions of culverts among the study streams to determine the degree to which culverts change flow patterns (Fig. 1). We recorded locations of culverts during site visits with a wide area augmentation system-enabled handheld global positioning system (GPS; GPSMap ${ }^{\circledR}$ 76CSx; Garmin, Olathe, Kansas). We downloaded and mapped GPS coordinates with ArcMap 9.2 (Environmental Systems Research Institute, Redlands, California).

We measured water velocity in 26 culverts at 11 different road crossings to compare velocity inside culverts to in-stream conditions. These sites represented perennial, $2^{\text {nd }}$ - to $4^{\text {th }}$-order streams (Strahler 1957) crossed by roads with culverts. Two of the road crossings studied were within the Carp Lake River watershed, whereas the remaining culvert sites were part of the Maple River watershed. We made all measurements during summer low-flow conditions (3-7 August 2008) - a time when crayfish movement is most pronounced (Flint 1977, Correia 1998). We used a Marsh-McBirney (Flo-Mate Model 2000; Marsh-McBirney, Frederick, Maryland) electromagnetic velocity meter to measure stream velocity $5 \mathrm{~cm}$ above the bed to reflect conditions experienced by crayfish. We measured flow at 6 equally spaced positions perpendicular to the axis of flow at a location inside the culvert near the outfall. We measured stream velocities $\sim 50 \mathrm{~m}$ upstream from the road crossing at 12 equidistant positions across the nearest riffle or run and used a paired-sample $t$-test to compare the mean culvert vs in-stream velocities among the 11 study streams.

\section{Crayfish capture, food, and housing}

We collected crayfish for all field and laboratory tests from rivers in Emmet County, Michigan, from June to August 2007 and 2008. We collected crayfish with baited minnow traps set overnight. We maintained $O$. propinquus and $O$. virilis at the University of Michigan Biological Station (UMBS) Stream Research Facility in 2 tanks (width $=0.6 \mathrm{~m}$, depth $=0.2 \mathrm{~m}$, length $=2.5 \mathrm{~m}$ ) constantly supplied with Maple River water. To avoid introduction of $O$. rusticus into the Maple River, we housed this species at UMBS Stockard Lakeside Lab in a similar-sized tank (length $=0.65 \mathrm{~m}$, depth $=0.35 \mathrm{~m}$, width $=3 \mathrm{~m}$ ) supplied with Douglas Lake water. We provided all crayfish with broken clay pots for shelters and fed them dry dog food and detritus ad libitum. Prior to testing, we labeled crayfish with white Papermate ${ }^{\circledR}$ correction fluid, measured the carapace length (CL) of each individual, and determined their sex and species. All label marks remained intact during the study.

\section{Crayfish behavior in culverts under different flow velocities}

We quantified the behavior of O. propinquus in 3 culverts with different mean flow velocities $(2,31$, and $42 \mathrm{~cm} / \mathrm{s}$ ) to assess how water velocity influenced crayfish movements in culverts. We selected this species because it was the only taxon commonly found among the river segments near the testing culverts. Prior to testing, we painted the interior culvert walls at each groove $(6.75-\mathrm{cm}$ intervals) up to $\sim 1 \mathrm{~m}$ upstream and downstream of the starting location so we could record crayfish position during experiments. We measured culvert flow velocities ( $5 \mathrm{~cm}$ above the bed) at 6 equally spaced positions perpendicular to the axis of flow at the starting location and $1 \mathrm{~m}$ upstream and downstream. The testing section was positioned $\geq 7 \mathrm{~m}$ from the culvert openings to provide adequate distance for the development of a flow boundary layer (Keller et al. 2003) and to ensure approximately equal light intensity from upstream and downstream ends of the culvert. During testing, observers were stationed $0.5 \mathrm{~m}$ upstream and downstream of the test area but maintained a position outside of the water to avoid disturbing crayfish and flow. It was too dark inside culverts to observe crayfish, so observers used headlamps covered with red plastic sheeting to minimize disturbance to crayfish. We placed a single crayfish in a 1-mm-mesh net at the starting location and allowed it to move away from the net into the water. Observers recorded crayfish position every $30 \mathrm{~s}$ and counted all slips, defined as involuntary, rapid downstream movements. Trials lasted a maximum of $10 \mathrm{~min}$ or until an individual moved $1 \mathrm{~m}$ upstream or downstream of the starting location. We conducted all trials between 1000 and $1700 \mathrm{~h}$ on 4-6 August 2007. We tested 30 individuals ( $n=10 /$ factor) and used animals only once.

We used analysis of covariance (ANCOVA) with $\mathrm{CL}$ as a covariate to compare the elapsed trial time (dependent variable) among flows (independent variable). This model included a CL $\times$ flow interaction term. We used a Mann-Whitney $U$ test (Sokal and Rohlf 1995) to compare the number of slips (dependent variable) of animals tested at 31 and $42 \mathrm{~cm} / \mathrm{s}$ because no crayfish slipped in the $2 \mathrm{~cm} / \mathrm{s}$ flow trials and the data were based on counts. We estimated separate least-squares linear regression models to characterize the relationship between CL 
(independent variable) and trial time (dependent variable) for crayfish tested in culverts with a mean flow of 2,31 , or $42 \mathrm{~cm} / \mathrm{s}$.

\section{Interspecific behavioral comparisons}

We quantified and compared the ability of the 3 crayfish species to traverse a single culvert in the field. We chose a culvert in the Carp Lake River for this trial because of its accessibility, large size, and high range of flow velocities. We modified flow conditions in the target culvert by creating a debris dam in an adjacent culvert. We marked the walls inside the culvert (described above) to define a 2-m test section, which was positioned $9 \mathrm{~m}$ downstream of the inflow to provide adequate distance for establishment of a well developed flow boundary layer (Keller et al. 2003). Before each trial, we measured flow velocities at the upstream, middle, and downstream portions of the test section with the protocol described above.

We tracked $O$. virilis $(n=17)$, O. propinquus $(n=15)$, and O. rusticus $(n=15)$ using only 1 crayfish/trial. Observers followed the same protocol for O. propinquus trials described above. Orconectes rusticus and O. virilis are most active at night (TAK, personal observation), so we conducted trials between 2130 and $0130 \mathrm{~h}$. We randomized the order of tests within and among species and used individual crayfish only once.

We used an independent-samples $t$-test to compare the flow velocity (dependent variable) within the culvert between the $1^{\text {st }}$ and $2^{\text {nd }}$ testing days (independent variable). We declared a trial successful when the crayfish moved $1 \mathrm{~m}$ upstream from its initial position in $<10 \mathrm{~min}$. We compared the number of successful trials (dependent variable) among species (independent variable) with a Fisher Exact Probability test (Sokal and Rohlf 1995). We used ANCOVA with CL as the covariate to compare the length of trials (dependent variable) among species (independent variable). We used a Bonferroni method $(\alpha /$ number of comparisons, Sokal and Rohlf 1995) to correct for inflation of type I error rate for all pairwise, post hoc comparisons (SPSS 15 for Windows; SPSS, Chicago, Illinois).

\section{Crayfish flow impedance velocity}

We used a recirculating, propeller-driven laboratory flume to determine the flow velocity that halted upstream movement (i.e., impedance velocity) for the 3 crayfish species. The working section of the flume was $100 \mathrm{~cm}$ long, $17.8 \mathrm{~cm}$ wide, and $14.5 \mathrm{~cm}$ deep. We placed a plastic collimator $(25 \mathrm{~cm}$ long $\times 15 \mathrm{~cm}$ high $\times 17.8 \mathrm{~cm}$ wide with $0.7 \times 0.7-\mathrm{cm}$ openings) between the inflow and the working section of the flume to reduce flow oscillations induced by propeller rotation. We mimicked the substrate and flow conditions in the culverts by placing a new section of galvanized metal culvert material on the bottom of the working section. Each culvert corrugation was $6.75 \mathrm{~cm}$ wide $\times 1.5 \mathrm{~cm}$ deep to match those used in field experiments. We glued a rubber mat ( $17.5 \mathrm{~cm}$ long $\times 17.8 \mathrm{~cm}$ wide) to the culvert material nearest the outflow to provide crayfish with a nonslip substrate from which to start the flow trials.

We manipulated flume water velocity with a rheostat-controlled propeller. We quantified propeller speed (as rpm) with a digital tachometer. We then characterized the relationship between propeller rpm and water velocity with a Marsh-McBirney flow meter. First, we measured flow velocity at 50-rpm intervals from 550 to $1500 \mathrm{rpm}$. We took all measurements $5 \mathrm{~cm}$ above the bed to match our field measurements. Second, we used least-squares linear regression to model the relationship between $\mathrm{rpm}(x)$ and flow velocity $(y)\left(y=0.0004 x-0.0376, r^{2}=0.99\right)$.

We measured impedance velocity for 90 crayfish ( $n=32$ O. rusticus, $n=29$ O. propinquus, $n=29$ O. virilis) between 2130 and $2400 \mathrm{~h}$. We randomized the order of tests within and among species and used no animal more than once. We started trials by placing a single crayfish on the rubber mat with a 1-mm-mesh nylon aquarium net. Once the animal moved out of the net and off the mat, we gradually increased the propeller speed. Trials ended when the crayfish remained stationary for $>5 \mathrm{~s}$ while trying to move upstream. We recorded the tachometer reading and estimated the water velocity with the regression model described above. We set initial velocity for all flow impedance tests to $21 \mathrm{~cm} / \mathrm{s}$. We included trials for 22 O. rusticus, 21 O. virilis, and 21 O. propinquus in the final data. We omitted from the analysis crayfish that refused to move or that used edges of the culvert material to move upstream. These crayfish did not provide an accurate estimate of the flow tolerance of crayfishes because edges do not exist in installed culverts (TAK, unpublished data). We used ANCOVA (covariate $=\mathrm{CL}$ ) to test whether impedance velocity differed among species. We made post hoc comparisons with a Bonferroni method to reduce type I error associated with multiple pairwise comparisons.

\section{Results}

\section{Culvert characteristics and locations}

Culverts averaged $15.3 \pm 1.7 \mathrm{~m}( \pm \mathrm{SE})$ in length and $1.7 \pm 0.2 \mathrm{~m}$ in diameter among the 11 road crossings. Most (58\%) crossings had 2 culverts, fewer (33\%) had 3 culverts, and only 1 crossing had 1 culvert. Of the 26 culverts evaluated, 4 were dry and 2 were inaccessible. Thus, our comparisons were limited to 8 road- 


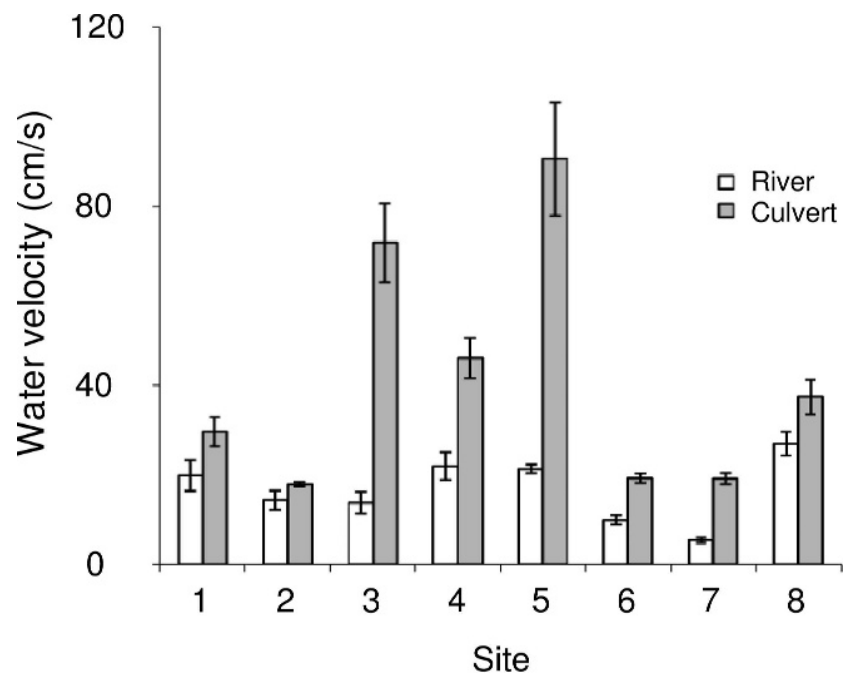

FIG. 2. Mean ( \pm 1 SE) water velocity in rivers and culverts among sites in the Carp Lake and Maple Rivers. Values were estimated using 6 flow measurements in each culvert and 12 flow measurements in the nearest riffle section $\sim 50 \mathrm{~m}$ upstream of each culvert.

crossing sites. Mean flow velocities within culverts were $157 \%$ higher than velocities measured in nearby river reaches (paired $t$-test, $t=2.82, \mathrm{df}=7, p=0.013$ ). In some cases, velocities were $>4 \times$ higher in culverts than in rivers (Fig. 2). Six culverts were elevated above the bed by 3.5 to $20.5 \mathrm{~cm}$. No similar natural steps (e.g., water falls) were found in any of the upstream surveys of these rivers.

\section{Crayfish behavior in culverts under different flow velocities}

Orconectes propinquus altered its movement in culverts at different flow speeds. At $2 \mathrm{~cm} / \mathrm{s}, O$. propinquus moved upstream in $70 \%$ of trials, and all

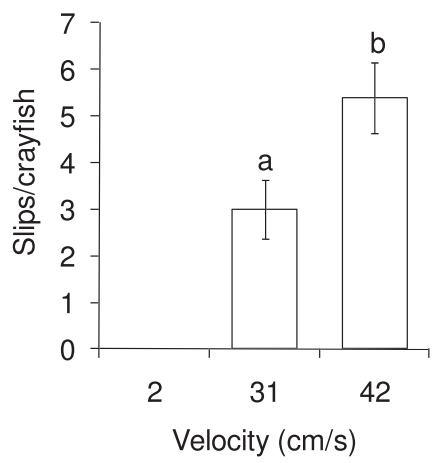

Fig. 3. Mean ( \pm 1 SE) number of slips per crayfish (Orconectes propinquus) tested in culverts with flow velocities of 2, 31, and $42 \mathrm{~cm} / \mathrm{s}$ ( $n=10$ for each). Trials ended after $10 \mathrm{~min}$ or after crayfish moved $1 \mathrm{~m}$ upstream or downstream from their starting position. Bars with the same letter are not significantly different $(p>0.05)$.

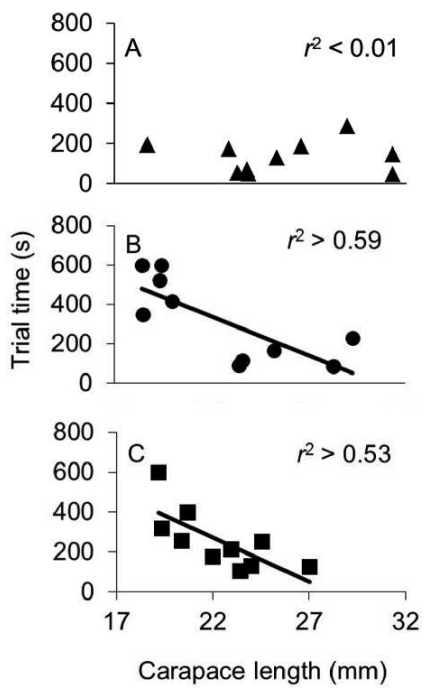

FIG. 4. Association between carapace length of the crayfish Orconectes propinquus and time individuals spent in culverts with flow velocities of 2 (A), 31 (B), and $42 \mathrm{~cm} / \mathrm{s}$ (C). Trials ended after $10 \mathrm{~min}$ or after animals moved $1 \mathrm{~m}$ upstream or downstream from their starting position. Lines were generated using least-squares linear regression. The $r^{2}$ indicates the associated coefficient of determination for the best-fit linear model.

crayfish moved $>1 \mathrm{~m}$ upstream or downstream during the 10-min observation period. Most (85\%) crayfish tested in higher-flow $(\geq 30 \mathrm{~cm} / \mathrm{s})$ culverts moved upstream $\geq 1 \mathrm{~m}$. Crayfish slipped more frequently while moving upstream in culverts with a flow velocity of $42 \mathrm{~cm} / \mathrm{s}$ than in culverts with a flow velocity of $31 \mathrm{~cm} / \mathrm{s}(U=20.5, n=20, p=0.023)$, and no crayfish slipped at $2 \mathrm{~cm} / \mathrm{s}$ (Fig. 3). Smaller crayfish (Wald $\chi^{2}=21.2, \mathrm{df}=1, p<0.0001$ ) and higher culvert velocity (Wald $\chi^{2}=16.2, \mathrm{df}=2, p=0.0003$ ) increased the mean time of trials. The association between trial time and CL depended on water velocity (Wald $\chi^{2}=$ $16.2, \mathrm{df}=2, p=0.0009$ ). No relationship was found between trial time and CL at $2 \mathrm{~cm} / \mathrm{s}\left(r^{2}<0.001, p=\right.$ 0.9 ; Fig. $4 \mathrm{~A})$. In contrast, large crayfish had progressively shorter trials than smaller individuals at 31 and $42 \mathrm{~cm} / \mathrm{s}\left(r^{2}>0.52\right.$, both $p \approx 0.017$; Fig. 4B, C).

\section{Interspecific behavioral comparisons}

We combined crayfish observations collected on 2 different nights to test the hypothesis that O. rusticus performed better than its congeners in culverts. This decision was justified because mean flow conditions were $29.2 \pm 0.008 \mathrm{~cm} / \mathrm{s}$ ( $\pm \mathrm{SE}$ ) on the first night and $30.2 \pm 0.008$ on the second $(t=0.77, \mathrm{df}=34, p=0.44)$. Crayfish species differed in their tolerance of high flow. Orconectes propinquus (93\% of those tested) and O. rusticus (87\%) moved $1 \mathrm{~m}$ upstream (within $10 \mathrm{~min}$ ) 
more often than did O. virilis $(50 \%, p=0.017)$. In addition, $C L$ and crayfish species influenced the time of trial (Wald $\chi^{2}=5.6, \mathrm{df}=1, p=0.018$; Wald $\chi^{2}=$ $14.2, \mathrm{df}=2, p=0.0008$; respectively). Orconectes rusticus and $O$. propinquus had similar trial times $(p \geq 0.9)$, but both species completed trials faster than O. virilis ( $p \leq 0.005$ for both; Fig. 5A).

\section{Crayfish flow impedance velocity}

Laboratory flume results were consistent with field experiments. CL (Wald $\chi^{2}=21.0, \mathrm{df}=1, p<0.0001$ ) and species (Wald $\chi^{2}=31.6, \mathrm{df}=2, p<0.0001$ ) influenced impedance velocity of crayfish. Large crayfish had higher impedance velocities than smaller individuals. The 3 species differed in their impedance velocities ( $p<0.04$ for all comparisons; Fig. 5B). Mean impedance velocity for O. rusticus was $7.7 \mathrm{~cm} / \mathrm{s}(24 \%)$ higher than $O$. virilis and $5.6 \mathrm{~cm} / \mathrm{s}(16.5 \%)$ higher than O. propinquus (Fig. 5B).

\section{Discussion}

Much of the evidence implicating culverts as a cause of fragmentation in streams derives from studies of free-swimming fishes (e.g., Warren and Pardew 1998, Peake 2004). Our study demonstrated that flow within culverts also may hamper upstream movement of large benthic organisms, such as crayfish. Culverts tend to be a cost-effective engineering solution to drainage problems (Johnson and Brown 2000, Gibson et al. 2005, Wargo and Weisman 2006), making them an attractive alternative to bridges at road-stream crossings. In Washington and Oregon, the US Forest Service and the Bureau of Land Management maintain roads with an estimated 10,000 culverts in streams containing fish (GAO 2001). Results of a study of Canada's coastal streams crossed by the Trans-Labrador Highway indicate that culverts have been used extensively in locations other than the US Northwest (Gibson et al. 2005). In northern Michigan, we found culverts at most road-stream crossings. With 1 exception, all road-stream intersections we studied had multiple culverts, a strategy that presumably reduces their effect on stream geomorphology (Wargo and Weisman 2006) by decreasing outfall flow velocities. However, even at sites with multiple culverts, we documented many cases where culverts increased flow velocity (Fig. 2) and created hydraulic drops. These conditions could create barriers to large benthic species (e.g., crayfishes) that crawl upstream.

Culverts do not necessarily create barriers. Rather, elevated flow velocities in culverts appear to alter crayfish behavior and slow their upstream movement.
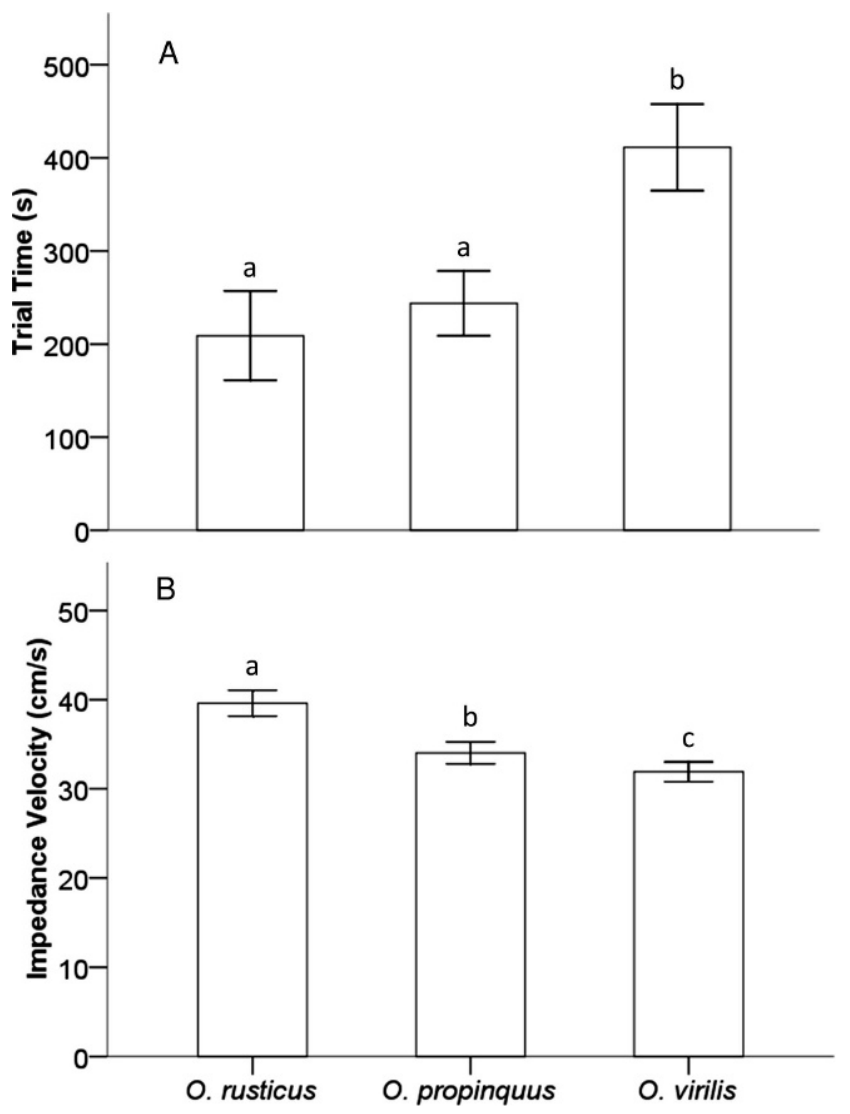

FIG. 5. Mean ( $\pm 1 \mathrm{SE}$ ) trial time (A) and impedance velocity (B) of the crayfish Orconectes rusticus, Orconectes propinquus, and Orconectes virilis. Trials ended when crayfish moved $1 \mathrm{~m}$ upstream of their starting position in a culvert with water velocity of $30 \mathrm{~cm} / \mathrm{s}$ (10 min maximum). Impedance velocity was designated as the maximum flow speed in a flume that prevented crayfish upstream movement. Bars with the same letter are not significantly different $(p>0.05)$.

Orconectes propinquus moved upstream more slowly and slipped more often in culverts with flow velocities $>30 \mathrm{~cm} / \mathrm{s}$. At these velocities, crayfish could move upstream, and nearly all animals oriented toward and moved in an upstream direction. In contrast, crayfish crawling downstream with the current did so only at low velocity $(2 \mathrm{~cm} / \mathrm{s})$. Crayfish may reduce their likelihood of being dislodged from the substrate by orienting head-first toward the flow in high-velocity conditions (Clark et al. 2008). Thus, crayfish at high flows appear to use movement strategies that decrease their risk of downstream displacement.

Orconectes propinquus was able to move $1 \mathrm{~m}$ upstream against a flow of $42 \mathrm{~cm} / \mathrm{s}$, but whether it could successfully navigate the length of an entire culvert is unknown. We estimate that $O$. propinquus would require $\sim 1 \mathrm{~h}$ of constant movement to pass through a 15-m-long 
culvert at $40 \mathrm{~cm} / \mathrm{s}$. This estimate does not account for how other factors, such as obstacles inside the culvert and fatigue, influence crayfish passage. However, additional obstacles probably would lengthen the time needed to traverse a culvert.

Some organisms, such as smallmouth bass (Peake 2004), can alter their swimming behavior to overcome flows in culverts. However, crayfish are limited to 2 main modes of locomotion: tail-flips and crawling. Tail-flips involve backwards swimming above the bed. This mode of locomotion is an effective antipredator escape response (Herberholz et al. 2004), but crayfish would be exposed to the upper extremes of the vertical velocity gradient by swimming above the bed. In this zone, they would have to expend even more energy to swim against high flows. We observed tail-flipping only once in 77 culvert trials, and that animal moved only $2 \mathrm{~m}$ upstream before being carried downstream. Thus, crawling upstream is likely to be the most common mode of upstream movement for crayfish because it allows the animal to assess its location and maintain its position even when stopped. We observed that crayfish in this mode lowered their bodies and extended their chelae forward, a behavior that may reduce drag (Maude and Williams 1983).

Body size influences the ability of a crayfish to tolerate flow. Clark et al. (2008) reported that small crayfish were generally more successful than larger crayfish in highflow areas. However, they tested animals in conditions with natural rock substrates. Culverts in northern Michigan streams rarely have such substrates (TAK, personal observation). The discrepancy between the findings of Clark et al. (2008) and our results may be partially explained by the fact that smaller crayfish can find refuges in crevices among rocks. This behavior presumably reduces their exposure to high-velocity currents and decreases drag. In culverts, the challenge of moving upstream in high-flow conditions appears to lie partially in the animal's ability to move over the ridges in the pipe corrugations. In our trials, many crayfish slipped when moving over ridges (HRF and TAK, unpublished data), where they were elevated and directly exposed to currents. In contrast, the troughs of the corrugations would reduce the frontal exposure of the crayfish to flow and might have eddies that would help a crayfish maintain its position or assist it in moving upstream.

All of the stream reaches we studied were within the normal range of velocities that permit crayfish to move upstream. However, we estimate that $20 \%$ of culvert sites studied probably were impassable to crayfish even during summer low-flow conditions. We designated sites as impassible/fragmented when the mean flow velocities exceeded the upper quartile of a species' impedance velocity. We set the upper quartile operationally because these velocities would exceed those that could be tolerated by $75 \%$ of all animals. These threshold values were calculated as $44.5,38.3$, and $36.3 \mathrm{~cm} / \mathrm{s}$ ( $5 \mathrm{~cm}$ above the bottom) for O. rusticus, O. propinquus, and O. virilis, respectively. We suggest that these thresholds are reasonable, given that animals would have to endure these flow conditions for $\geq 15 \mathrm{~m}$ at many road crossings. Target velocities for these habitats must be set much lower to ensure passage by these crayfishes.

Field observations of crayfish in culverts and laboratory measurements of their impedance velocity were generally consistent. However, some differences did exist. The discrepancies might be explained by the characteristics of culvert material used in field and laboratory experiments. In the field, metal culverts develop thick scale during oxidation. This alteration of the metal surface can create interstices that enable crayfish to maintain their position under elevated flow. In contrast, we constructed our laboratory flume experiments with new unoxidized culvert material that mimicked physical conditions found in recently installed culverts. Thus, the textural differences between field and laboratory culverts might explain why crayfish tested in the laboratory exhibited lower tolerance for flow than those in the field.

Seasonal variation in stream discharge and crayfish activity probably influence the degree of aquatic habitat fragmentation caused by culverts. Our study was conducted in the summer when stream discharges are near their minimum. For example, flow measurements in Carp River decreased by 50\% from June to August 2008. The summer warm period also is when crayfish are most active (Flint 1977, Correia 1998). Thus, the flow conditions we tested should have reflected conditions at the time of typical crayfish dispersal. Therefore, our results should provide a reasonable estimate of the degree to which flow in culverts impedes crayfish upstream movement on an annual basis.

Flow in culverts also may act as a selective environmental filter that differentially favors some species over others. In both field and laboratory trials, $O$. rusticus was significantly more adept at moving upstream than $O$. propinquus or $O$. virilis. The disparity between species was most profound between $O$. rusticus and $O$. virilis because $O$. rusticus tolerated culvert flow velocities $24 \%$ higher than did O. virilis. The ecological implications for native species could be profound if culvert conditions differentially select nonindigenous over native species. Upstream, native populations could be more susceptible to extinction resulting from their limited 
population size, reduced migration from downstream populations, and decreased gene flow. These threats are further exacerbated when nonindigenous species migrate through barriers and compete with the natives for resources (Gamradt and Kats 1996).

The 3 crayfish species we studied are ubiquitous throughout the northern midwestern US. However, many crayfishes are endangered or threatened, often because of their limited range (Taylor et al. 1996). Limits on the dispersal of imperiled crayfish by habitat fragmentation from culverts may reduce population size and accelerate rates of extirpation. The loss of crayfish populations could have important implications for the trophic dynamics of aquatic ecosystems (Momot et al. 1978).

Our findings can provide some guidance regarding strategies to minimize the impact of culverts on stream crayfish. Flow velocity influences the success of crayfish passage, so engineers should consider ways to reduce water velocity inside culverts, particularly during seasons of active dispersal. Options to improve biotic passage through the culverts could include installing the pipes with lower slopes, increasing the number of pipes, increasing the installation depth of the pipes, and expanding the diameter of installed culverts. In addition, bottomless culverts with natural substrates could greatly encourage the passage of benthic species by providing appropriate natural substrates and refuges from flow. Alternative culvert designs that include areas of flow refuge could help facilitate passage of fish and invertebrates (Larinier 2002). The requirements of the full range of lotic organisms that would be forced to use culverts for upstream or downstream passage should be considered when deciding whether to install culverts or bridges.

\section{Acknowledgements}

We thank Mark Hunter, Bob Vande Kopple, and Paul Moore for their assistance with important elements of this research project. Financial and logistical support was provided by the Frontiers Program at the University of Michigan, University of Michigan Biological Station, and Columbus State University. Comments by Jack Feminella and 2 anonymous referees improved the quality of this manuscript.

\section{Literature Cited}

Benton, P. D., W. E. Ensign, and B. J. Freeman. 2008. The effect of road crossings on fish movements in small Etowah Basin streams. Southeastern Naturalist 7: 301-310.

ButLer, M. J. 1985. An analysis of the mechanisms governing species replacements in crayfish. Oecologia (Berlin) 66: 168-177.
Capelli, G. M. 1982. Displacement of northern Wisconsin crayfish by Orconectes rusticus (Girard). Limnology and Oceanography 27:741-745.

Capelli, G. M., And B. L. Munjal. 1982. Aggressive interaction and resource competition in relation to species displacement among crayfish of the genus Orconectes. Journal of Crustacean Biology 2:486-492.

Clark, J. M., M. W. Kershner, and J. R. Holomuzki. 2008. Grain size and sorting effects on size-dependent responses by lotic crayfish to high flows. Hydrobiologia 610:55-66.

Corey, S. 1988. Comparative life histories of 2 populations of the introduced crayfish Orconectes rusticus (Girard, 1852) in Ontario. Crustaceana 55:29-38.

CorreiA, A. M. 1998. Seasonal and circadian foraging activity of Procambarus clarkii (Decapoda, Cambaridae) in Portugal. Crustaceana 17:158-166.

Creaser, E. P. 1931. The Michigan decapod Crustaceans. Papers of the Michigan Academy of Sciences, Arts and Letters 13:257-276.

CREed, R. P. 1994. Direct and indirect effects of crayfish grazing in a stream community. Ecology 75:2091-2103.

FAHRIG, L. 2003. Effects of habitat fragmentation on biodiversity. Annual Review of Ecology, Evolution, and Systematics 34:487-515.

Fischer, J., AND D. B. LindenMAYER. 2007. Landscape modification and habitat fragmentation: a synthesis. Global Ecology and Biogeography 16:265-280.

FLINT, R. W. 1977. Seasonal activity, migration and distribution of the crayfish, Pacifastacus leniusculus, in Lake Tahoe. American Midland Naturalist 97:280-292.

Gamradt, S. C., And L. B. Kats. 1996. Effect of introduced crayfish and mosquitofish on California newts. Conservation Biology 10:1155-1162.

GAO (General Accounting Office). 2001. Restoring fish passage through culverts on Forest Service and BLM lands in Oregon and Washington could take decades. GAO-02-136. General Accounting Office, Washington, DC.

Garvey, J. E., R. A. Stein, And H. M. Thomas. 1994. Assessing how fish predation and interspecific prey competition influence a crayfish assemblage. Ecology 75:532-547.

Gibson, R. J., R. L. HaEdrich, AND C. M. Wernerheim. 2005. Loss of fish habitat as a consequence of inappropriately constructed stream crossings. Fisheries 30(1):10-17.

Haro, A., T. Castro-Santos, J. Noreika, and M. Odeh. 2004. Swimming performance of upstream migrant fishes in open-channel flow: a new approach to predicting passage through velocity barriers. Canadian Journal of Fisheries and Aquatic Sciences 61:1590-1601.

Hazlett, B. A., P. Acquistapace, and F. Gherardi. 2002. Differences in memory capabilities in invasive and native crayfish. Journal of Crustacean Biology 22: 439-448.

Hazlett, B. A., F. E. Anderson, L. A. Esman, C. Stafford, And E. Munro. 1992. Interspecific behavioral ecology of the crayfish Orconectes rusticus. Journal of Freshwater Ecology 7:69-76. 
Herberholz, J., M. M. Sen, ANd D. H. Edwards. 2004. Escape behavior and escape circuit activation in juvenile crayfish during prey-predator interactions. Journal of Experimental Biology 207:1855-1863.

HiLl, A. M., D. M. SinARS, AND D. M. Lodge. 1993. Invasion of an occupied niche by the crayfish Orconectes rusticuspotential importance of growth and mortality. Oecologia (Berlin) 94:303-306.

Johnson, P. A., AND E. R. BRown. 2000. Stream assessment for multicell culvert use. Journal of Hydraulic Engineering 126:381-386.

JONES, S. N., AND E. A. BERGEY. 2007. Habitat segregation in stream crayfishes: implications for conservation. Journal of the North American Benthological Society 26:134-144.

Keller, T. A., I. Powell, and M. J. Weissburg. 2003. Role of olfactory appendages in chemically mediated orientation of blue crabs. Marine Ecology Progress Series 261:217-231.

LARINIER, M. 2002. Fish passage through culverts, rock weirs and estuarine obstructions. Bulletin Français de la Pêche et de la Pisciculture 364(Supplement):119-134.

Lodge, D. M., C. A. Taylor, D. M. Holdich, and J. SKurdal. 2000. Nonindigenous crayfishes threaten North American freshwater biodiversity: lessons from Europe. Fisheries 25(8):7-20.

Maude, S. H., AND D. D. Williams. 1983. Behavior of crayfish in currents: hydrodynamics of eight species with reference to their distribution patterns in southern Ontario. Canadian Journal of Fisheries and Aquatic Sciences 40:68-77.

Момот, W. T. 1984. Crayfish production-a reflection of community energetics. Journal of Crustacean Biology $4: 35-54$.

Момот, W. T. 1995. Redefining the role of crayfish in aquatic ecosystems. Reviews in Fisheries Science 3:33-63.

Mомот, W. T., H. Gowing, AND P. D. Jones. 1978. Dynamics of crayfish and their role in ecosystems. American Midland Naturalist 99:10-35.

Ormerod, S. J. 2003. Current issues with fish and fisheries: editor's overview and introduction. Journal of Applied Ecology 40:204-213.

Park, D., M. Sullivan, E. Bayne, And G. Scrimgeour. 2008. Landscape-level stream fragmentation caused by hanging culverts along roads in Alberta's boreal forest. Canadian Journal of Forest Research 38:566-575.

PEAKE, S. 2004. An evaluation of the use of critical swimming speed for determination of culvert water velocity criteria for smallmouth bass. Transactions of the American Fisheries Society 133:1472-1479.

PRINGLE, C. M. 1997. Exploring how disturbance is transmitted upstream: going against the flow. Journal of the North American Benthological Society 16:425-438.
Pringle, C. M. 2001. Hydrologic connectivity and the management of biological reserves: a global perspective. Ecological Applications 11:981-998.

RABENI, C. F. 1992. Trophic linkage between stream centrarchids and their crayfish prey. Canadian Journal of Fisheries and Aquatic Sciences 49:1714-1721.

SOKAL, R. R., AND F. J. Rohlf. 1995. Biometry: the principles and practice of statistics in biological research. $3^{\text {rd }}$ edition. W. H. Freeman and Co., New York.

Statzner, B., E. Fievet, J. Y. Champagne, R. Morel, and E. Herouin. 2000. Crayfish as geomorphic agents and ecosystem engineers: biological behavior affects sand and gravel erosion in experimental streams. Limnology and Oceanography 45:1030-1040.

StrAHLER, A. N. 1957. Quantitative analysis of watershed geomorphology. Transactions of the American Geophysical Union 8:913-920.

Taylor, C. A., G. A. Schuster, J. E. Cooper, R. J. Distefano, A. G. Eversole, P. Hamr, H. H. Hobbs, H. W. Robison, C. E. Skelton, And R. E. Thoma. 2007. Endangered species a reassessment of the conservation status of crayfishes of the United States and Canada after 10+ years of increased awareness. Fisheries 32:372-389.

Taylor, C. A., M. L. Warren, J. F. Fitzpatrick, H. H. Hobbs, R. F. Jezerinac, W. L. Pflieger, and H. W. Robinson. 1996. Conservation status of crayfishes of the United States and Canada. Fisheries 23(4):25-38.

Utzinger, J., C. Roth, And A. Peter. 1998. Effects of environmental parameters on the distribution of bullhead Cottus gobio with particular consideration of the effects of obstructions. Journal of Applied Ecology 35: $882-892$.

Vaughan, D. M. 2002. Potential impact of road-stream crossings (culverts) on the upstream passage of aquatic macroinvertebrates. Submitted to US Forest Service by The Xerces Society. Portland, Oregon. (Available from: http:/ /www.xerces.org/wp-content/uploads/2008/09/ culvert-report.pdf)

WARGO, R. S., AND R. N. WEISMAN. 2006. A comparison of single-cell and multicell culverts for stream crossings. Journal of the American Water Resources Association 42:989-995.

Warren, M. L., AND M. G. PARdeW. 1998. Road crossings as barriers to small-stream fish movement. Transactions of the American Fisheries Society 127:637-644.

Wilcove, D. S., AND L. L. Master. 2005. How many endangered species are there in the United States? Frontiers in Ecology and the Environment 3:414-420.

Received: 6 July 2010 Accepted: 28 July 2011 
Copyright of Journal of the North American Benthological Society is the property of North American Benthological Society and its content may not be copied or emailed to multiple sites or posted to a listserv without the copyright holder's express written permission. However, users may print, download, or email articles for individual use. 